Relations industrielles

Industrial Relations

\title{
Job Search and Wage Behaviour
}

\section{Claude Rondeau}

Volume 31, numéro 2, 1976

URI : https://id.erudit.org/iderudit/028708ar

DOI : https://doi.org/10.7202/028708ar

Aller au sommaire du numéro

Éditeur(s)

Département des relations industrielles de l'Université Laval

ISSN

0034-379X (imprimé)

1703-8138 (numérique)

Découvrir la revue

Citer cet article

Rondeau, C. (1976). Job Search and Wage Behaviour. Relations industrielles /

Industrial Relations, 31(2), 303-309. https://doi.org/10.7202/028708ar

Tous droits réservés (C Département des relations industrielles de l'Université Laval, 1976
Ce document est protégé par la loi sur le droit d'auteur. L’utilisation des services d'Érudit (y compris la reproduction) est assujettie à sa politique d'utilisation que vous pouvez consulter en ligne.

https://apropos.erudit.org/fr/usagers/politique-dutilisation/ 


\section{COMMENTAIRES}

\section{JOB SEARCH AND WAGE BEHAVIOUR}

\section{Claude Rondeau}

Recent studies in job search theory emphasize the importance of unemployment duration and of the level of aspiration in the determination of the asking wage of job seekers. The job searcher is assumed to exhibit an adaptive aspiration level which results in a declining level of the asking wage as the duration of unemployment increases (Holt, 1970). ${ }^{1}$

On the other hand, Mackay (1972) has suggested an interesting hypothesis with respect to job search strategy which, if further supported, would shed additional light on the behaviour of job searchers. According to this hypothesis, some job searchers, called «stickers", will accept relatively long periods of unemployment after lay-off in order to find a job comparable to the one previously held in terms of wage and stability of employment. Others, called «snatchers», are «multiple job changers »; they exhibit less overall unemployment but an initially greater fall in wages; eventually, however, snatchers recoup these losses by moving the higher wage levels and better jobs.

The purpose of this note it to examine asking wages and accepted wages of workers involved in a mass lay-off, in the light of these propositions. The data were collected in the Spring of 1971 through a questionnaire mailed to 3026 blue- and white-collar workers laid-off by a large aeronautical firm in the Montreal area over a fifteen-month period from January 1970 to March 1971. Out of a total of 1209 questionnaires returned, 212 were rejected mainly because of inconsistent replies with respect to dates of employment. Table 1 describes the sample used. Of the 997 cases studied, 593 were continuously unemployed (Group A), 152 accepted one or more temporary jobs (Group B),

* C. RONDEAU, Professeur agrégé, École des relations industrielles, Université de Montréal, Montréal.

** Premilinary analysis of the data must be credited to my research assistant Bernard Elie. Gilles Guérin, Léo Roback and Claude D'Aoust read the first draft and their suggestions improved the clarity of the text.

1 Most authors, with the exception of Mortensen (1970), assume a declining asking wage through a period of unemployment; see Kasper (1967), McCall (1970), Gronau (1970). Holt is emphasized here because his concept of the level of the asking wage is clearer. 
72 accepted at least one temporary job but were permanently employed at the time of inquiry (Group C), and 180 never had a temporary job and were permanently employed at the time of inquiry (Group D). The meaning of Group A is self-evident. Group B is seen as made up of «snatchers» or «multiple job changers». Group C is also seen as a group of «snatchers», with the difference that a permanent job was found and accepted after a number of jobs had been held temporarily. Group D is defined as a group of "stickers", i.e. those who waited in order to find a job which they considered permanent. Much of the analysis which follows rests upon these distinctions. They are based on a preliminary treatment of the data which showed that jobs labeled as temporary were of significantly shorter average duration than jobs labeled as permanent $;^{2}$ moreover, two thirds of the workers holding permanent jobs said they had no intention of quitting voluntarily. Finally, the average number of temporary jobs held was 1.5 for group $\mathrm{B}$ and 1.8 for group $\mathrm{C}$ (not counting the permanent job in the latter case). Thus although the distinction is not as clear cut as one might desire, it appears strong enough for our purposes, and justifies the use of the concepts of «snatchers " and «stickers».

TABLE 1

\section{Description of sample}

\begin{tabular}{|c|c|c|c|c|c|}
\hline $\begin{array}{l}\text { Group } \\
\text { Identification }\end{array}$ & $\begin{array}{l}\text { Group A } \\
\text { Continuous } \\
\text { unemployment }\end{array}$ & $\begin{array}{l}\text { Group B } \\
\text { Temporary } \\
\text { employment } \\
\text { (snatchers) }\end{array}$ & $\begin{array}{l}\text { Group C } \\
\text { Temporary } \\
\text { and perma- } \\
\text { nent em- } \\
\text { ployment } \\
\text { (snatchers) }\end{array}$ & $\begin{array}{l}\text { Group D } \\
\text { Permanent } \\
\text { 'mployment } \\
\text { (stickers) }\end{array}$ & Total \\
\hline $\mathrm{n}$ & 593 & 152 & 72 & 180 & 997 \\
\hline$\%$ & 59.5 & 15.2 & 7.2 & 18.1 & 100.0 \\
\hline $\begin{array}{l}\text { Average number } \\
\text { of jobs }\end{array}$ & 0 & 1.5 & 2.8 & 1.0 & - \\
\hline $\begin{array}{l}\text { Average duration } \\
\text { of lay-off (days) } \\
\text { Average duration } \\
\text { of unemployment (days) }\end{array}$ & 168 & 294 & 313 & 261 & 228 \\
\hline
\end{tabular}

We shall analyse the behaviour of these four groups with respect to minimum asking wages, accepted wages in temporary and/or permanent employment, and total unemployment duration. It should be noted that for multiple job changers (groups B and C), accepted wage rates have been averaged over all jobs occupied. ${ }^{3}$ The level of aspi-

\footnotetext{
2 Average duration of permanent jobs was 177.4 days for group $\mathrm{D}$; average durations of temporary jobs varied between 4.8 days and 98.3 days for groups B and C.

3 Various wage rates accepted were found to be randomly distributed over jobs.
} 
ration is defined as the minimum wage acceptable by the job searcher. ${ }^{4}$ Unemployment duration is the number of days spent looking for work (excluding time in employment) after lay-off and up to the time of inquiry. ${ }^{5}$

Two additional remarks are necessary before the results are presented and discussed. During the 15 month period covered here, the unemployment rate averaged $8.3 \%$ in Quebec, ranging from $8.0 \%$ in January 1970 to $6.3 \%$ in September 1970 and over $10 \%$ in the first quarter of 1971. Secondly, the lay-offs were administered through the Quebec reclassification program; this program is described in Sexton (1974); according to Sexton, the reclassification measures may have some impact on the behaviour of job searchers.

\section{RESULTS}

Table 2 shows average wage rates asked (minimum) and accepted by each group of job searchers, as a percentage of the last wage before lay-off. Table 3 is similar, but introduces the duration of unemploy-

TABLE 2

One-way analysis of variance, contrasts and T-test.- Average asking changes (minimum) and accepted wage changes, by job search strategy.

Groups

\begin{tabular}{|c|c|c|c|c|c|c|c|}
\hline & & A & B & $\mathrm{C}$ & D & $F(p)$ & Contrasts $(p)$ \\
\hline $\begin{array}{l}\text { Minimum } \\
\text { wage } \\
\text { demands }\end{array}$ & $\begin{array}{l}\bar{x} \\
\mathrm{~s} \\
\mathrm{n}\end{array}$ & $\begin{array}{r}-12.145 \\
15.362 \\
593\end{array}$ & $\begin{array}{r}-11.614 \\
16.575 \\
152\end{array}$ & $\begin{array}{r}-12.251 \\
14.803 \\
72\end{array}$ & $\begin{array}{r}-8.129 \\
18.619 \\
180\end{array}$ & $\begin{array}{r}3.3053 \\
(.0197)\end{array}$ & $\begin{array}{l}\text { A-D }(.002) \\
\text { B-D }(.050) \\
\text { C-D }(.067)\end{array}$ \\
\hline $\begin{array}{l}\text { Accepted } \\
\text { wages }\end{array}$ & $\begin{array}{l}\bar{x} \\
\mathrm{~s} \\
\mathrm{n}\end{array}$ & & $\begin{array}{r}-5.338 \\
26.603 \\
152 \\
-3.27 \\
.001\end{array}$ & $\begin{array}{r}-8.459 \\
20.271 \\
72 \\
-1.88 \\
.064\end{array}$ & $\begin{array}{r}-6.885 \\
27.758 \\
180 \\
-0.71 \\
.481\end{array}$ & $\begin{array}{l}0.3698 \\
(.6911)\end{array}$ & $\begin{array}{l}\text { None } \\
\text { signif. }\end{array}$ \\
\hline
\end{tabular}

Note: Only contrasts significant at the $5 \%$ level are reported.

4 This is not entirely consistent with Holt's model. Moreover, due account must be taken of Rottenberg's remarks on the value of responses to questions on job choice (Rottenberg. 1956).

5 Note that lay-offs were spread evenly over the entire fifteen-month period. Average durations of lay-off are shown in table 1. Only 16 individuals had been laid off less than 30 days. The analysis reported here was repeated, excluding those 16 , and yielded similar results. 
ment ${ }^{6}$ into the analysis. The method used is one-way analysis of variance and multiple contrasts among the group means. ${ }^{7}$ T-tests are used when two sample means only are compared. ${ }^{8}$

Table 2 shows that, with respect to minimum asking wages, «snatchers» (Groups B and C) and continuously unemployed job seekers (Group A) appear to constitute one homogeneous grouping, while «stickers» (Group B) stand out as significantly different from all other groups. On the other hand, when accepted wages are considered, «snatchers» and «stickers» show no significant difference. Moreover, accepted wages are significantly different from asking wages for «snatchers», but not for «stickers». This may be interpreted as reflecting a relative insensitivity of the minimum asking wage to unemployment, except when the job seeker does accept what he considers to be a permanent job. This would imply that the job search strategy, or the reemployment path chosen, might play a major role in the determination of the wage behaviour of job searchers.

Table 3 lends some support to this deduction. Whether unemployment lasted less or more than one month had no significant effect on the minimum asking wages for all groups. In terms of accepted wages, however, "stickers» appear to have performed much better if they accepted a job in the first month of unemployment, while «snatchers » maintained approximately the same level of performance.

\section{DISCUSSION}

It is important to bear in mind that the sample of job searchers under discussion was drawn from one firm in one urban labor market. However, inferences drawn from these results provide significant indications which may be useful in the orientation of further research.

For the sample of job searchers under study, it has been found that job search strategy seems to be a much more important variable than unemployment duration in the determination of wage behaviour. It would appear, then, that changes in the level of wage aspirations, if they occur, are insignificant throughout the period of unemployment. An adjustment in the level of aspirations would occur, for obvious reasons, only when the job searcher is willing to accept a job which

6 The two subclasses of unemployment duration were established after extensive preliminary analysis. When data for all groups were pooled, it was found that, in terms of wage behaviour, a clear out-off point appeared around thirty days of unemployment. Nevertheless, in order to increase the size of Groups $C_{1}$ and $D_{1}$ the analysis was repeated, using other subclasses of unemployment duration; the results obtained were not significantly different from those reported here. Contrasts $B_{1}-B_{2}$ and $C_{1}-$ $\mathrm{C}_{2}$ were checked more than once and are not significant, even at the $10 \%$ level.

7 The analysis of variance technique is standard and is explained in Guenther (1974)

$8 \quad$ The program used was SPSS, CDC version 5.8 . 
TABLE 3

One-way analysis of variance and contrasts.-

Average asking wage changes (minimum) and accepted wage changes, by job search strategy and duration of unemployment.

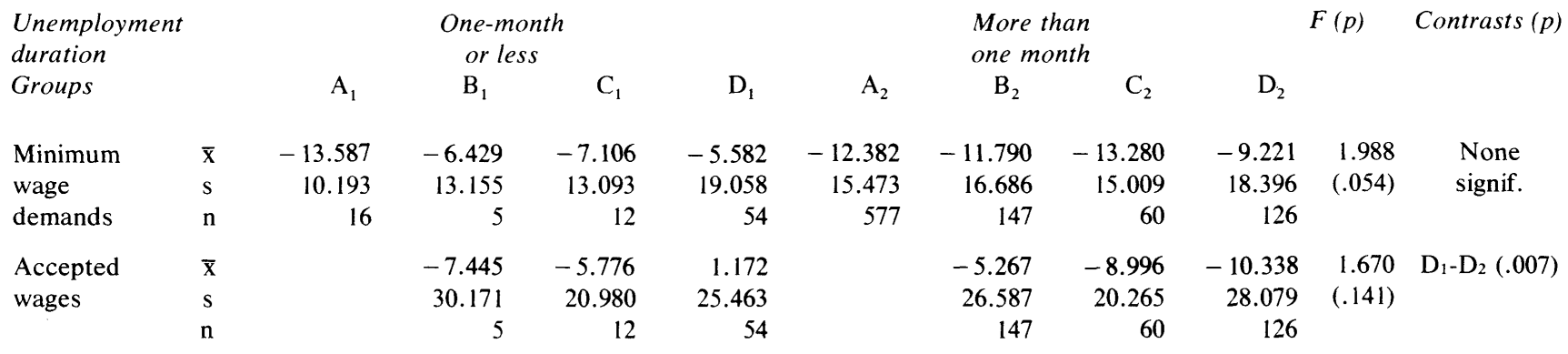

Note: Only contrasts significant at the $5 \%$ level are reported. 
he considers permanent. However, the duration of unemployment would then affect the level of accepted wages. In other words, aspirations remain relatively unchanged during job search; however, the longer unemployment lasted, the lower accepted wages would be.

Holt's assumption of an aspiration level declining through the period of unemployment would thus appear to be unnecessary, at least when aspirations are set at a minimum level. Of course, this conclusion probably results from such a definition of wage aspirations, and there is no claim here that one essential element of Holt's model is disproved. However, a job searcher may have in mind, at any given moment, a number of different and possibly conflicting levels of aspiration. ${ }^{9}$ Our results suggest that the pattern of behaviour may depend significantly on which aspiration level is given a greater weight; this, in turn, may be affected by the job search strategy chosen by the worker. ${ }^{10}$

Indeed, the job search strategy hypothesis does receive some support here. However, this hypothesis should probably be modified in the light of our results. There is no evidence that «stickers» do better than «snatchers» do, except during the first month of unemployment. On the other hand, there is some evidence that wages accepted by both «snatchers" and «stickers" tend to be lower after a month's unemployment than what «stickers» have accepted earlier. Thus, losses incurred by adopting a "snatcher's » strategy immediately after lay-off would not be recovered by moving later on to higher-paying jobs. In pratical terms, this suggests that a job searcher should adopt a «sticker's « strategy during the first few weeks of unemployment; if this fails, he should then resort to a «snatcher's» strategy and accept temporary jobs in order to lower the cost of search and minimize his losses.

\section{REFERENCES}

R. GRONAU, (1971). «Information and Frictional Unemployment». American Economic Review, vol. 61, no. 3, June 1971, pp. 290-301.

William C. GUENTHER, (1964). Analysis of Variance. Englewood Cliffs, N.J.: Prentice-Hall.

Charles C. HOLT, (1970). «Job Search, Phillips'Wage Relation, and Union Influence: Theory and Evidence» in E.S. Phelps et al., Microeconomic Foundations of Employment and Inflation Theory; New York: W.W. Norton and Co. Inc.

9 See Lewin (1944) for a discussion of the concept of level of aspiration.

10 These results also lend support to Mortensen's hypothesis of a constant minimum asking wage. This would suggest the possibility that the job searcher has an indeterminate time horizon, which is another way of saying that unemployment duration has no significant effect on the searcher's wage behaviour. 
H. KASPER, (1967). "The Asking Price of Labour and the Duration of Unemployment. "Review of Economics and Statistics, vol. 49, no. 2, May 1967, pp. 965-972.

K. LEWIN, (1944) et al., "Level of Aspiration» in J.M. Hunt(ed). Personality and the Behavior Disorders; New York: Ronald Press.

D.I. MACKAY, (1972). «After the Shake-Out». Oxford Economic Papers, vol. 24, no. 1, March 1972, pp. 89-110.

J.J., McCALL, (1970). «Economics of Information and Job Search». Quarterly Journal of Economic's, vol. 84, no. 1, February 1970, pp. 113-125.

D.T. MORTENSEN, (1970). «Job Search, the Duration of Unempioyment and the Phillips Curve». American Economic Review, vol. 60, no. 5, December 1970, pp. 847-862.

S. ROTTENBERG, (1956). «On choice in Labor Markets». Industrial and Labor Relations Review, vol. 9, no. 2, January 1956, pp. 183-199.

J. SEXTON, (1974). Blue-Collar Workers Displaced by Complete and Permanent Plant Shutdowns - The Quebec Experience. Unpublished Ph. D. Dissertation. Cornell University.

\title{
A NOTE ON INDUSTRIAL CONFLICT IN BRITISH COLUMBIA'S CONSTRUCTION INDUSTRY
}

\author{
Joseph B. Rose
}

Since the publication of the Goldenberg inquiry into construction labour relations in Ontario (1962), the industrial relations system in construction has come under increasing scrutiny. ${ }^{1}$ Studies by Goldenberg and Crispo ${ }^{2}$, Woods ${ }^{3}$ and Rose ${ }^{4}$ have explored such topics as the structure, performance and issues of collective bargaining, the certification process, and the accreditation of contractor associations.

J. B. Rose, Assistant Professor, School of Administration, University of New Brunswick, Fredericton, N.B.

1 Report of the Royal Commission on Labour-Management Relations in the Construction Industry, H. Carl Goldenberg, Commissioner, Ontario, 1962.

2 H. Carl GOLDENBERG and John H. G. CRISPO, eds., Construction Labour Relations, Ottawa, Canadian Construction Association, 1968.

3 Report of the Commission of Enquiry into Industrial Relations in the Nova Scotia Construction Industry, H. D. Woods, Commissioner, Halifax, Nova Scotia Department of Labour, 1970.

4 Joseph B. ROSE, Report on Accreditation and the Construction Industry, Fredericton, New Brunswick Department of Labour, 1972. 